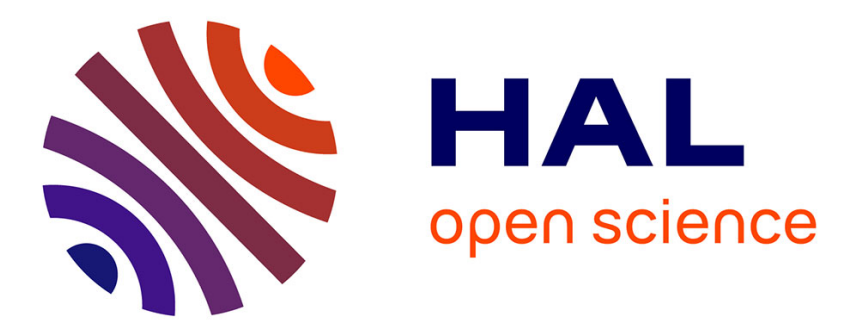

\title{
Buildings Vulnerability Assessment and Damage Seismic Scenarios at Urban Scale: Application to Chlef City (Algeria)
}

\author{
Zohra Boutaraa, Caterina Negulescu, Ahmed Arab, Olivier Sedan
}

\section{- To cite this version:}

Zohra Boutaraa, Caterina Negulescu, Ahmed Arab, Olivier Sedan. Buildings Vulnerability Assessment and Damage Seismic Scenarios at Urban Scale: Application to Chlef City (Algeria). KSCE Journal of Civil Engineering, 2018, 22 (10), pp.3948-3960. 10.1007/s12205-018-0961-2 . hal-02734388

\section{HAL Id: hal-02734388 \\ https: / hal-brgm.archives-ouvertes.fr/hal-02734388}

Submitted on 1 Sep 2020

HAL is a multi-disciplinary open access archive for the deposit and dissemination of scientific research documents, whether they are published or not. The documents may come from teaching and research institutions in France or abroad, or from public or private research centers.
L'archive ouverte pluridisciplinaire HAL, est destinée au dépôt et à la diffusion de documents scientifiques de niveau recherche, publiés ou non, émanant des établissements d'enseignement et de recherche français ou étrangers, des laboratoires publics ou privés.

\section{(c)(1)}

Distributed under a Creative Commons Attribution| 4.0 International License 


\title{
Buildings Vulnerability Assessment and Damage Seismic Scenarios at Urban Scale: Application to Chlef City (Algeria)
}

\author{
Zohra Boutaraa*, Caterina Negulescu**, Ahmed Arab***, and Olivier Sedan****
}

\begin{abstract}
Seismic scenarios are tools used to assess seismic risk at the city level. This allows the assessment of the vulnerability of exposed elements to risk (buildings, bridges, etc.). In the case of Chlef city (formerly El Asnam), this evaluation type proves to be useful given the seismic hazard to which it is exposed and the building park size. This city has been shaken in the past by several earthquakes including that of the El Asnam $1980(M s=7.3)$, which caused hundreds of casualties and destroyed $70 \%$ of the city. In this paper, a seismic vulnerability assessment at urban scale and three seismic damage scenarios are simulated using the "RISK-UE" methodology. First, a recreation of the El Asnam 1980 earthquake, considering the urban conditions of the 1980s, is done. A difference of about $12 \%$ between observed and simulated damage is observed. Secondly, two senarios considering the current urban conditions are simulated then, vulnerabilty curves are developed. The simulations purpose is to detect the most vulnerable typologies and districts in the event of a similar earthquake and to provide decision support elements to the local seismic risk manager. The results show a structural damage decrease compared to the 1980 urban conditions.
\end{abstract}

Keywords: El Asnam earthquake, building seismic vulnerability, LM1 method, damage scenarios, Chlef city

\section{Introduction}

The simulation of damage scenarios, which is part of seismic vulnerability studies, is a valuable tool for assessing seismic risk. Various categories of damage and losses can be assessed through seismic damage scenarios: damage to buildings, human casualties and socio-economic losses related to the interruption of activities, Dolce et al. (2003). Across the world, studies have been conducted to assess seismic risk in general and to establish strategies to mitigate this risk. Cases of recent urban resilience studies can be cited as the one carried out by Ferreira (2017) for the city center of Horta (Portugal). Other European cities have benefited from studies of seismic risk and buildings vulnerability assessment, such as, Angra do Heroísmo by Veludo et al. (2013) and Lisbon by Lamego et al. (2016). In Algeria, since the 2003 Boumerdes earthquake $(M s=6.3)$, seismic vulnerability assessment studies of buildings throughout some large cities of Algeria have been carried: such as those done for Algiers by Farsi and Lazzali, 2003; Amina et al., 2010; Novelli et al., 2015, for Constantine city Boukri et al., 2014; Benhamouche, 2014; Guettiche et al., 2017, for Oran city by Senouci et al. (2013) and for Annaba city by Athmani et al. (2015).

Among the most widely used methods for assessing the buildings seismic vulnerability in Europe is the Risk-UE methodology, whose LMI level is used in this study. This methodology, described in Milutinovic and Trendafiloski (2003), is an advanced approach to earthquake risk scenarios with application to different European towns. It has two levels: the $L M 1$ method, which is favoured as suitable for vulnerability, damage and loss assessments in urban environments having not detailed site specific seismicity estimates but adequate estimates on the seismic intensity. This method, called "macroseismic" method, is based on observed damage data and on the EMS98 buildings classification. It requires the seismic action to be defined in terms of macroseismic intensity, and the seismic quality of the buildings to be described by means of a vulnerability index, Lantada et al. (2010).To evaluate this vulnerability index, the $L M 1$ method provides a classification system based on a building typology matrix BTM with 23 principal building classes grouped by structural types and material of construction. Behaviour modifiers including other aspects affecting the building seismic performance are added. This method, is applied to asses the buildings vulnerability in this study. The LM2 method, is applicable for urban environments possessing detailed micro seismicity studies expressed in terms of site-specific spectral quantities such as spectral acceleration, spectral velocities or spectral displacements, Milutinovic and Trendafiloski (2003).

\footnotetext{
*Ph.D. Candidate, Materials Sciences and Environment Laboratory, Hassiba Ben Bouali University of Chlef(02000), Algeria. (Corresponding Author, Email: z-djezzar2016@hotmail.com)

**Researcher, BRGM (French Geological Survey), 3 Avenue Claude Guillemin, 45060 Orléans Cedex 2, France (E-mail: c.negulescu@brgm.fr) ***Researcher, BRGM (French Geological Survey), 3 Avenue Claude Guillemin, 45060 Orléans Cedex 2, France (E-mail: o.sedan@brgm.fr) ****Professor, Materials Sciences and Environment Laboratory, Hassiba Ben Bouali University of Chlef (02000), Algeria (E-mail: ah_arab@yahoo.fr)
} 
In the case of Chlef city, the damaged buildings inventory done by the CTC (Construction Technical Control) following the 1980 El Asnam earthquake on 5131 buildings, presents a precious data source which can be used to study the behaviour of these buildings in response to earthquakes and to perform seismic damage scenarios. In this context, this article aims to detect the most vulnerable buildings typologies and districts in Chlef city in the case of a seismic event and, consequently, to provide elements for decision support to the local community in charge of seismic risk management. Through the use of a GIS (Geographic Information System) tool, a graphical data platform is developed and, the Armagedom software, Sedan et al. (2013) is used for the simulation of seismic damage scenarios. Three seismic damage scenarios are presented in this paper:

- The first one consists in the recreation of the October 10, $1980 \mathrm{El}$ Asnam earthquake $(M s=7.3)$ considering the urban area and the buildings' characteristics of the 1980s. The results are compared with the damage observed after 1980 . Two values of the $t$ parameter of the Beta distribution are considered and their influence on the results is explained;

- The second one consists in the simulation of an earthquake with similar intensity of that of $1980 \mathrm{El}$ Asnam earthquake considering current urban expansion;

- The third scenario consists of to simulate the Red Mountains fault potential earthquake which can, according to WCC (1984), generate an earthquake of a maximum magnitude of 6.3 .

\section{Description of the Study Area}

Chlef city, formerly named El Asnam, is the $10^{\text {th }}$ largest city in Algeria and is located $200 \mathrm{~km}$ west of the capital Algiers. Fig. 1 shows the geographical situation of Chlef city (El Asnam) and its location in Chlef province.

Concerning the seismic hazard, Chlef region is characterized by shallow seismicity and active faulting Beldjoudi et al. (2012) and is ranked in zone III (high seismicity) by the Algerian earthquake regulations RPA (2003). It's has been the site of several destructive earthquakes during the last century: 1922 Abou Elhassen earthquake $(M s=5.9) ; 1954$ Orleansville earthquake $(M s=6.7)$ and $1980 \mathrm{El}$ Asnam earthquake $(M s=7.3)$. This last earthquake, caused more than 2,700 casualties, 12,000 injured and over 150,000 homeless. During these events, the MMI measured seismic intensity was of $I X$ to $X$ (Hamdache et al., 2010; Ayadi and Bezzeghoud, 2015). Thus, numerous geological and seismological studies have been carried out since the $1980 \mathrm{El}$ Asnam earthquake. These studies pointed out the complexity of reverse fault zones and the evolution of the related seismicity in Chlef region (Meghraoui et al., 1988; Bezzeghoud et al., 1995; Aoudia et al., 2000; Yelles-Chaouche et al., 2006; Meghraoui and Pondrelli, 2012). Fig. 2 shows the seismotectonic map of Chlef region, which includes the active Cheliff Basin folding and the associated El Asnam active fault (Oued Fodda fault) responsible for the 1980 earthquake. In this figure, the square numbered 1 is the historical event of Carnot $1934\left(I_{0}=I X\right)$ and the circles numbered 2 and 3 are the instrumental seismic events of $1954\left(I_{0}=X\right)$ and of $1980\left(I_{0}=I X \sim X\right)$. The main active faults are: F1, offshore fault; F2, Abou-El-Hassan fault; F3, BledBahari-Karouch fault; F4, Oued Fodda fault; F5, Ouled-Farès and Red Mountains faults. AA' is a cross-section.

\section{Chlef Buildings' Park in 1980 and Today}

The buildings present in Chlef city in 1980 can be divided into three categories: Masonry buildings that survived the 1954 earthquake, RC moment frames built between 1954 and 1962, and those constructed after 1962. It should be noted that, prior to 1954, there were no seismic code in Algeria. The buildings constructed between 1954 and 1962 followed the recommendations established (AS55) in the aftermath of the devastating 1954 earthquake. Buildings built after 1962 were designed according to the French recommendations (PS69). In 1980 the housing stock did not exceed 5,150 buildings. During the 1980 earthquake, more

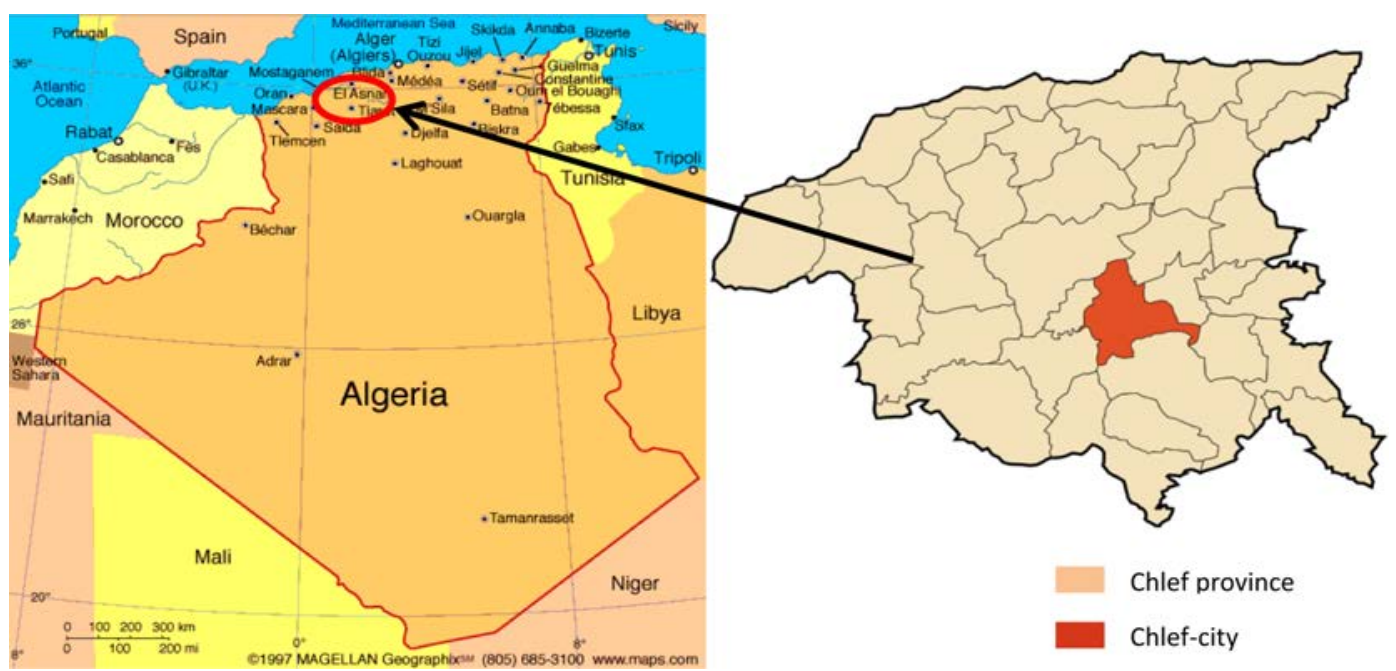

Fig. 1. Geographical Situation of Chlef City in Algeria (formerly El Asnam) and Its Location in Chlef Province 


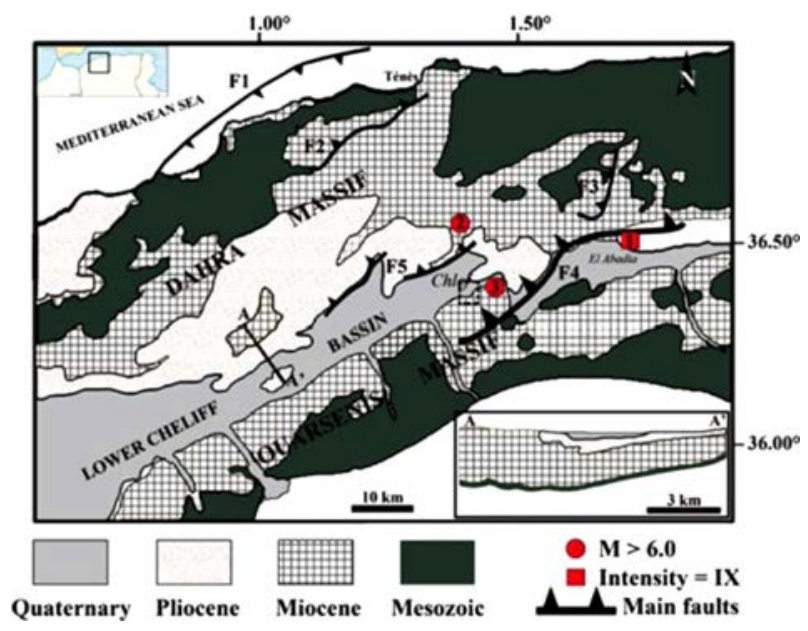

Fig. 2. Chlef Region Seismotectonic Map, Layadi et al. (2016)

than $70 \%$ of this park was destroyed. Currently, the buildings park in Chlef city consists of the remaining $30 \%$, in addition to the new constructive typologies: RC moment frames with brick infill (Fig. 3(a)), RC shear walls (Fig. 3(b)) and prefabricated single-family houses (Fig. 3(c)). A part of the buildings recovered from the earthquake were rehabilitated according to the Algerian seismic code RPA (2003) in its first version published in 1981. The other two typologies are conceived according to the same code with its different versions according to their years of realization. This code divides the country into four zones of seismicity: zone 0 (Negligible seismicity), zone I (Low seismicity), zone IIa (Moderate seismicity), zone IIb (High seismicity) and zone III (Very high seismicity). The code gives a design spectra (Fig. 4) for the different soil classes (S1: rock, S2: firm soil, S3: loose soil and S4: very loose soil) and two calculation methods: the equivalent static and the spectral modal analysis method. According to its different versions, the RPA (2003) can be devised in three levels: pre code: before 1980, low code: between

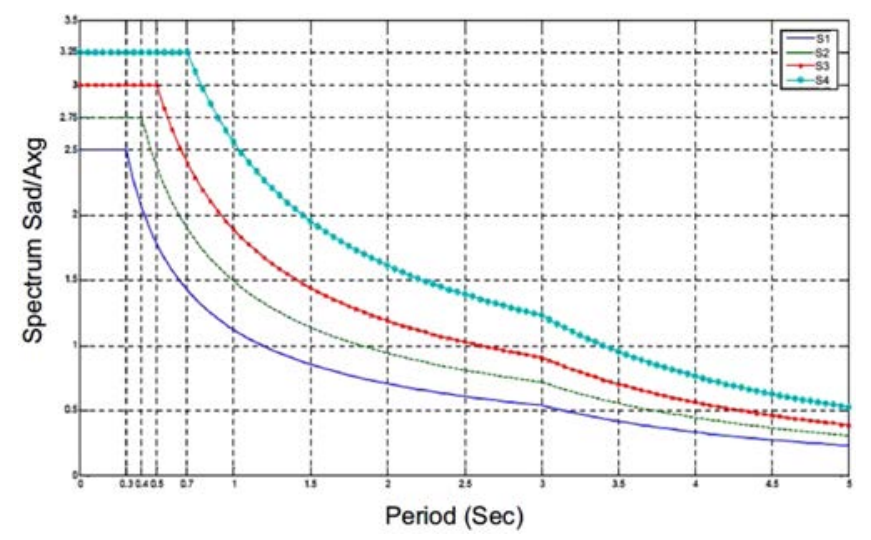

Fig. 4. Design Spectra Recommended by the Algerian Seismic Code RPA (2003)

1981 (first seismic code) and 1989 (first revision), medium code: between 1989 and 2003 (last revision) and high code: after 2003.

The current housing stock in Chlef city. consists of more than 22,053 buildings. Residential buildings represent 33,717 apartments, including single-family, multi-family and single-family prefabricated houses (Fig. 5(a)). The multi-family residential buildings represent a total number of 378 buildings. As it can be seen in Fig. 5(b), single-family residential buildings are predominant (77.61\%) compared to multi-family ones $(22.39 \%)$.

\section{Urban Damage Inventory after El Asnam Earthquake}

Following the $1980 \mathrm{El}$ Asnam earthquake, the CTC conducted a field investigation on 5,131 buildings in Chlef city to draw up a damage inventory. Within this aim, the city was divided into ten zones. MMI scale Intensity, used to describe the damage, was evaluated at $X$ in the city center and at $I X$ in the remaining zones, Bertero and Shah (1983). It should be noted that, according to
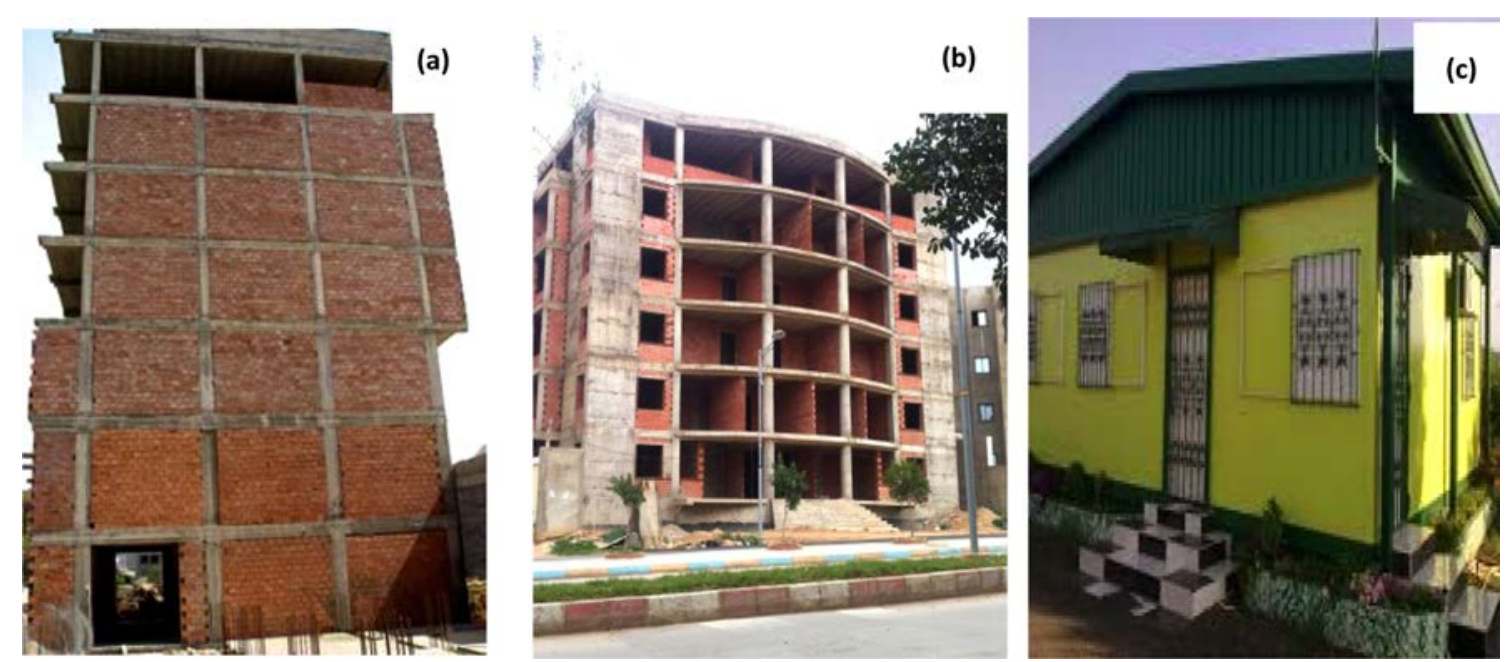

Fig. 3. The Main Building Typologies Existing in Chlef City Today: (a) RC Moment Frames (b), RC Shear Walls Buildings, (c) Prefabricated Houses 


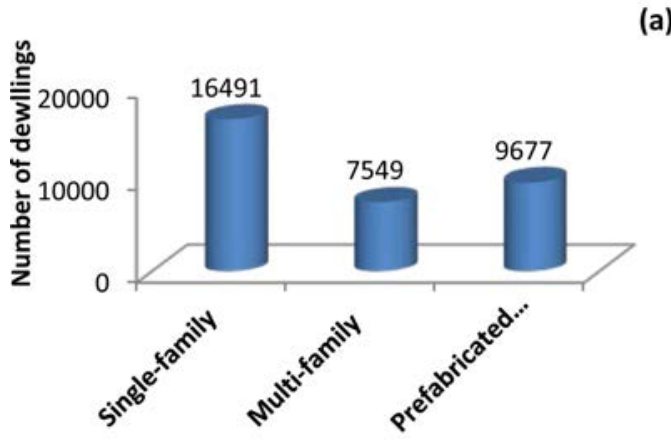

(a)

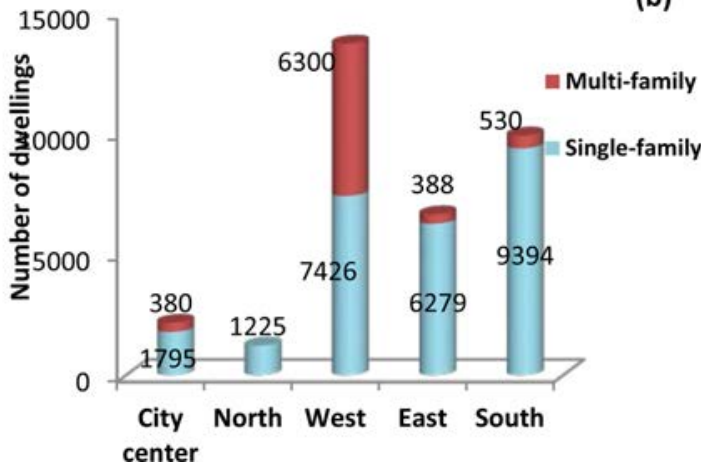

Fig. 5. Housing Stock Distribution in Chlef City in Terms of: (a) Dwelling Types, (b) Their Proportion by District



Fig. 6. Distribution of the Buildings Damage Following the $1980 \mathrm{El}$ Asnam Earthquake

Murphy and O'Brien (1977) the $M M I$ damage scale is equivalent to the EMS98 one. Based on this data, a buildings damage classification was established (Table 1) by Petrovski et al. (1981) and is illustrated in Fig. 6, on which the green columns represent the percentage of buildings that can be occupied immediately; the orange ones represent the percentage of those that require further study before being occupied or condemned and the red represent the percentage of condemned buildings that must be demolished.

\subsection{Buildings Damage Description}

Regarding the description of buildings in the studied-area,

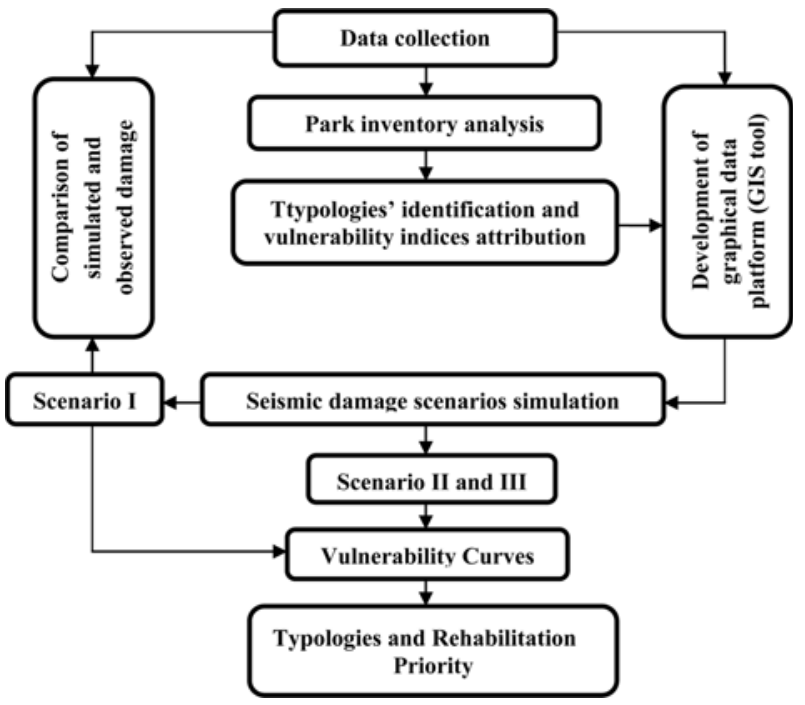

Fig. 7. Flowchart of the Adopted Methodology

some information exists in different databases such as the Earthquake Engineering Online Archive NISEE e-Library (NISEE), where a precise description of the behaviour of different constructions after the $1980 \mathrm{El}$ Asnam earthquake is presented. Farsi and Lazzali (2003) present a single-family RC moment frames house with a ground floor. Bertero and Shah (1983) give a quite good description or the failure modes after the $1980 \mathrm{E} 1$ Asnam earthquake of multi-family residential and

Table 1. Damage Classification Following the El Asnam Earthquake, Petrovski et al. (1981)

\begin{tabular}{|c|c|c|c|c|c|c|c|c|c|}
\hline \multirow{3}{*}{ Zone } & \multirow{3}{*}{$\begin{array}{l}\text { Total Number of } \\
\text { Buildings }\end{array}$} & \multicolumn{8}{|c|}{ Damage classification } \\
\hline & & \multicolumn{2}{|c|}{ Green } & \multicolumn{2}{|c|}{ Orange } & \multicolumn{2}{|c|}{ Red } & \multicolumn{2}{|c|}{ Undefined } \\
\hline & & Number & $\%$ & Number & $\%$ & Number & $\%$ & Number & $\%$ \\
\hline I & 566 & 108 & 19.08 & 341 & 60.24 & 116 & 20.49 & 1 & 0.17 \\
\hline II & 360 & 112 & 31.11 & 164 & 45.55 & 80 & 22.22 & 4 & 1.11 \\
\hline III & 715 & 154 & 21.53 & 322 & 45.03 & 238 & 33.28 & 1 & 0.13 \\
\hline IV & 256 & 97 & 37.89 & 98 & 38.28 & 61 & 23.82 & 0 & 0.00 \\
\hline $\mathrm{V}$ & 686 & 219 & 31.92 & 253 & 36.88 & 214 & 31.19 & 0 & 0.00 \\
\hline VII & 343 & 161 & 46.93 & 132 & 38.48 & 38 & 11.07 & 12 & 3.49 \\
\hline VIII & 367 & 156 & 42.50 & 157 & 42.77 & 40 & 10.89 & 14 & 3.81 \\
\hline IX & 490 & 136 & 27.75 & 243 & 49.59 & 99 & 20.20 & 2 & 2.44 \\
\hline X & 384 & 146 & 38.02 & 109 & 28.38 & 129 & 33.59 & 0 & 0.00 \\
\hline Total & 5,131 & 1,718 & 33.41 & 2,158 & 41.99 & 1,200 & 23.31 & 55 & 1.28 \\
\hline
\end{tabular}


administrative RC moment frames buildings with masonry or brick infill. These studies are at the base of the choice of the buildings vulnerability indices used in this study.

\section{Study Methodology}

The adopted methodology is represented by the flowchart of Fig. 7. It's based on the following key steps.

\subsection{Data Collection}

The collected data relate to buildings' characteristics (age, dimensions, design type, function, and possible rehabilitation after past earthquakes), number of buildings, El Asnam earthquake damage inventory and city graphical documents.

\subsection{Typologies, Vulnerability Indices and Vulnerability Curves}

In this study, the typologies classification and the assignment of vulnerability indices are done according to the developments provided by the LMI method, Lagomarsino and Giovinazzi (2006). The vulnerability index VI is introduced to represent and quantify the belonging of a building to a certain vulnerability class in order to quantify, in a conventional way, the building behaviour. Each building type is characterized by prevailing (most likely) vulnerability class. However, in accordance with the

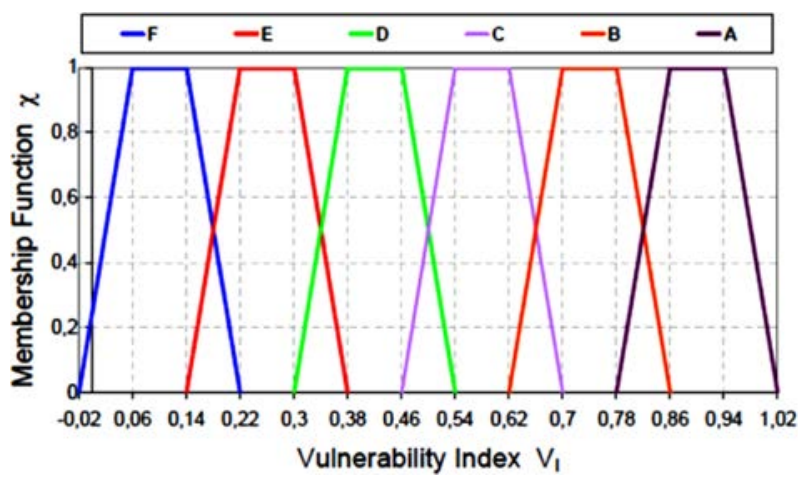

Fig. 8. Membership Functions and VI Values of the Six EMS98 Vulnerability Classes, Milutinovic and Trendafiloski (2003) buildings structural characteristics, it is possible to define possible and less probable vulnerability classes in the same building type. According to the fuzzy-set theory, the trapezoidal membership functions $\chi$ of the six vulnerability classes (Fig. 8) have a plausible $(\chi=1)$ and two linear possible ranges, defining the transition between two adjacent classes. $V I^{*}$ is the most probable or plausible value of the vulnerability index $(\chi=1)$; $\left[V I ; V I^{+}\right]$are the bounds of the plausible range of the vulnerability index $(\chi=0.6) ;\left[V I^{\min } ; V I^{\max }\right]$ are the upper and lower bounds of the possible values $(\chi=0.2)$ (Table 2). The LMI method provides a typological classification system in order to group structures with a similar seismic performance $V I$ class (Table 2), then adds behaviour modifiers $V m$ (Table 3) to evaluate the final vulnerability index of each building :

$$
V I_{\text {building }}=V I_{\text {class }}+\Delta V_{R}+\sum_{j=1}^{n} \Delta V_{m j}
$$

where,

$V I_{\text {class }}$ is the vulnerability index corresponding to the class of the building (Table 2)

$\Delta V_{R}$ is a regional modifier which takes into account the region characteristics. In this study, it is taken as equal to zero, and

$\Delta V_{m j}$ are behaviour modifiers including other aspects affecting the building seismic performance (Table 3).

\subsubsection{First Scenario (Chlef in 1980)}

For this scenario, three typologies are identified:

- Masonry buildings constructed before 1954 designated as $T A$ typology, class $C$ of the EMS98 scale is assigned to this typology and a $V I$ value equal to the upper bounds of the possible values $(V I=0.7)$;

- RC moment frames with masonry or brick infill buildings built between 1954 and 1962, designated as TB typology. For this typology a large behaviour variability has been observed during the1980 earthquake. Hence the typology can be assigned to both class $A$ and class $B$ of the EMS98 scale. To be in a median situation, the $V I$ value assigned is equal to 0.82 , which is the mean value of the two average vulnerability indices for each of the two classes; and

- RC moment frames with masonry or brick infill buildings built after 1962; designated as TC typology. A medium

Table 2. Vulnerability Index Values for Several Cases of the Building Typology Matrix (BTM) Milutinovic and Trendafiloski (2003)

\begin{tabular}{|c|c|c|c|c|c|c|}
\hline \multirow{2}{*}{ Typology } & \multirow{2}{*}{ Description } & \multicolumn{5}{|c|}{$V I$ representative value } \\
\hline & & $V I^{\min }$ & $V I$ & $V I^{*}$ & $V I^{+}$ & $V I^{\max }$ \\
\hline M1.1 & Rubble stone, fieldstone & 0.62 & 0.81 & 0.873 & 0.98 & 1.02 \\
\hline M1.2 & Simple stone & 0.46 & 0.65 & 0.74 & 0.83 & 1.02 \\
\hline M1.3 & Massive stone & 0.3 & 0.49 & 0.616 & 0.793 & 0.86 \\
\hline M3.4 & Unreinforced Masonry - R.C. floors & 0.3 & 0.49 & 0.616 & 0.793 & 0.86 \\
\hline M4 & Reinforced or confined masonry walls & 0.14 & 0.33 & 0.451 & 0.633 & 0.70 \\
\hline $\mathrm{RC} 2$ & RC shear walls & -0.02 & 0.047 & 0.386 & 0.67 & 0.86 \\
\hline RC3.1 & Regularly infilled walls & -0.02 & 0.007 & 0.402 & 0.76 & 0.98 \\
\hline $\mathrm{RC} 3.2$ & Irregular frames & 0.06 & 0.127 & 0.522 & 0.88 & 1.02 \\
\hline $\mathrm{RC} 4$ & $\mathrm{RC}$ dual systems (RC frame and wall) & -0.02 & 0.047 & 0.386 & 0.67 & 0.86 \\
\hline
\end{tabular}






Fig. 9. Exposed Elements Corresponding to the 1980 Situation Used in the First Damage Scenario

value of VI corresponding to vulnerability class $C$, which is the most probable value recommended by EMS 98 scale $(\chi=$ $1)$, is assigned to this typology $(V I=0.58)$.

\subsubsection{Second and Third Scenarios (Chlef today)}

For this two scenarios, the adaptation of the LMI method is sequenced around defining the code level according to the main construction periods. In order to make a difference between the same typology constructed before 1980 (pre-code) and after 2003 (high code), the vulnerability factor related to the code level equal to 0.16 (Table 3 ) is added and respectively subtracted.

Table 4 gives the vulnerability index attributed to each building typology, for the three scenarios.

The mean damage degree $\left(\mu_{D}\right.$ : between 0 and 5$)$ is estimated based on a vulnerability function by Eq. (2):

$$
\mu_{\mathrm{D}}=2,5\left[1+\tanh \left(\frac{I+6,25 V I-13,1}{Q}\right)\right]
$$

where:

$I$ is the seismic hazard described in terms of macroseismic intensity,

$V I$ the vulnerability index, and
Table 3. Scores for the Vulnerability Factors $V m$ Related to the Code Level for RC Buildings, Milutinovic and Trendafiloski (2003)

\begin{tabular}{c|c|c|c}
\hline \multirow{2}{*}{$\begin{array}{c}\text { Vulnerability } \\
\text { Factors }\end{array}$} & \multicolumn{3}{|c}{ ERD level } \\
\cline { 2 - 4 } & Pre or Low Code & Medium Code & High Code \\
\hline Code level & +0.16 & 0 & 0.16 \\
\hline
\end{tabular}

$Q$ the ductility index which is evaluated taking into account the building typology and its construction features. According to Giovinazzi (2005), the curves derived from EMS98 scale are characterized by $Q=2.3$.

Equation (2) allow us to establish vulnerability curves for the different typologies existing inboth urban situations. For this propurse, the mean damage degree $\mu_{D}$ is evaluated for each building typology using the vulnerability indices values (Table 4) and by varing the intensity $I$ from a value of $V$ to $X I I$.

\subsection{Development of the Graphical Data Platform}

Figures 9 and 10 represent the two maps of exposed elements developed using a GIS tool. Fig. 9 is used for the simulation of the first damage scenario. In 1980, zones I, II, III and IX (Table 1) were the most populated and urbanized districts, containing a total number of 3,166 buildings and suffered the most damage during the El Asnam 1980 earthquake. Therefore, only these four zones are considered in the simulation of the first scenario. To respect the order, zone IX will be numbered as zone 4. Based on the typological homogeneity of the various buildings, each of the four zones represented in this map is divided into several polygons. A total of 50 polygons are obtained. In order to identify the weight of the different typologies, the total number of buildings and the number of buildings in each typology are calculated for each zone (Table 5).

Figure 10 is used for the simulation of the second and the third damage scenarios. In this case, the city is divided into five zones (city center, north zone, south zone, east zone and west zone), which are delimited by natural elements (rivers) or man-made elements (railway, main road). In the same way as in the preceding scenario, each of the five zones is divided into several polygons. A total number of 276 polygons are obtained, containing

Table 4. Vulnerability Index Values Assigned to the Different Typologies

\begin{tabular}{|c|c|c|c|c|}
\hline Scenario & Typology & Structural type and period of construction & Code level & $\begin{array}{c}\text { Vulnerability } \\
\text { Index } V I\end{array}$ \\
\hline I & $\begin{array}{l}\text { TA } \\
\text { TB } \\
\text { TC }\end{array}$ & $\begin{array}{l}\text { Masonry buildings built before } 1954 \\
\text { RC moment frames built between } 1954 \text { and } 1962 \\
\text { RC moment frames built after } 1962\end{array}$ & $\begin{array}{l}- \\
\text { AS55 } \\
\text { PS62 }\end{array}$ & $\begin{array}{l}0.70 \\
0.82 \\
0.58\end{array}$ \\
\hline \multirow{7}{*}{ II and III } & TM & Masonry buildings built before 1954 & - & 0.616 \\
\hline & $\mathrm{T} 1$ & RC moment frames regularly infilled walls built before 1980 & Pre-code & 0.562 \\
\hline & $\mathrm{T} 2$ & RC moment frames regularly infilled walls built between 1981 and 2003 & Medium code & 0.402 \\
\hline & $\mathrm{T} 3$ & RC moment frames regularly infilled walls built after 2003 & High code & 0.242 \\
\hline & $\mathrm{T} 4$ & RC shear walls built between 1981 and 2003 & Medium code & 0.386 \\
\hline & T5 & RC shear wall built after 2003 & High code & 0.226 \\
\hline & TP & Prefabricated single-family houses & - & 0.3 \\
\hline
\end{tabular}




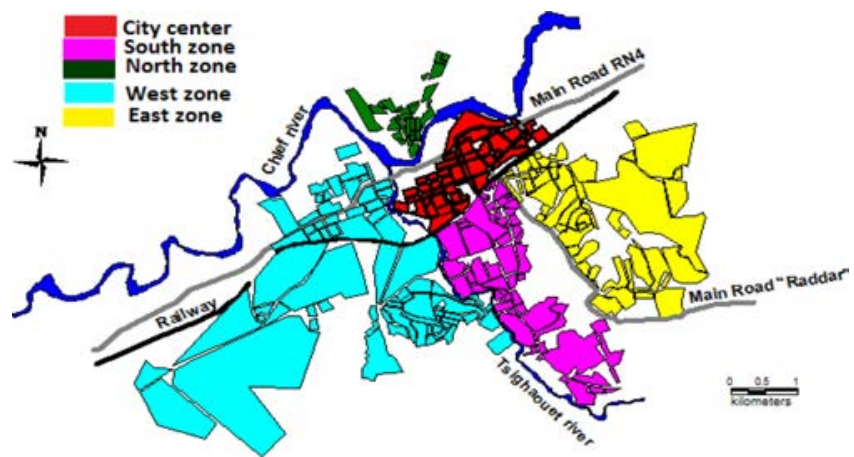

Fig. 10. Exposed Elements Corresponding to the Actual Urban Situation Used in the Second and Third Damage Scenarios

22,053 buildings.

\subsection{Seismic Damage Scenarios Simulation}

For the detailed damage assessment, the Armagedom software, Sedan et al. (2013) is used. To perform the damages scenarios, the user has the possibility to import a hazard map (e.g. ground motion field map). In this case, the intensity of the considering earthquake event is directly introduced. This was used for the first scenario and intensity of was introduced. The user can also generate an earthquake based on input parameters: seismic source (epicenter location or faults vector map), focal depth, magnitude, and attenuation law. Different attenuation laws can be used to calculate the PGA (Peak Ground Acceleration), which is converted in EMS98 intensity using either Atkinson and Sonley (2000) or Wald et al. (1999) equations. This second choice was used for the two last scenarios. The input parameters are the epicentre coordinate (36.13 N, 1.34 E), the focal depth of the El Asnam 1980 event (10 km), the magnitude: 7.3 and 6.3 for the second and third scenario respectively, and the Ambraseys et al. (2005) attenuation law. For the third damage scenario, a fault vector map was established in SIG

Table 5. Number of Buildings and Polygons (first damage scenario)

\begin{tabular}{c|c|c|c|c|c|c}
\hline \multicolumn{2}{c|}{ Number of buildings and polygons } & Zone 1 & Zone 2 & Zone 3 & Zone 4 & Total \\
\hline \multicolumn{2}{c|}{ Total number of buildings } & 754 & 399 & 1,402 & 611 & 3,166 \\
\hline \multirow{2}{*}{$T A$ typology } & Total number of polygons & 15 & 12 & 13 & 10 & 50 \\
\cline { 2 - 7 } & Number of buildings & 439 & 61 & 23 & - & 523 \\
\hline \multirow{2}{*}{$T B$ typology } & Number of polygons & 4 & 2 & 5 & - & 11 \\
\cline { 2 - 8 } & Number of buildings & 164 & 48 & 637 & 200 & 1,049 \\
\hline \multirow{2}{*}{$T C$ typology } & Number of polygons & 7 & 5 & 4 & 4 & 19 \\
\cline { 2 - 7 } & Number of buildings & 151 & 290 & 742 & 4 & 7 \\
\hline
\end{tabular}
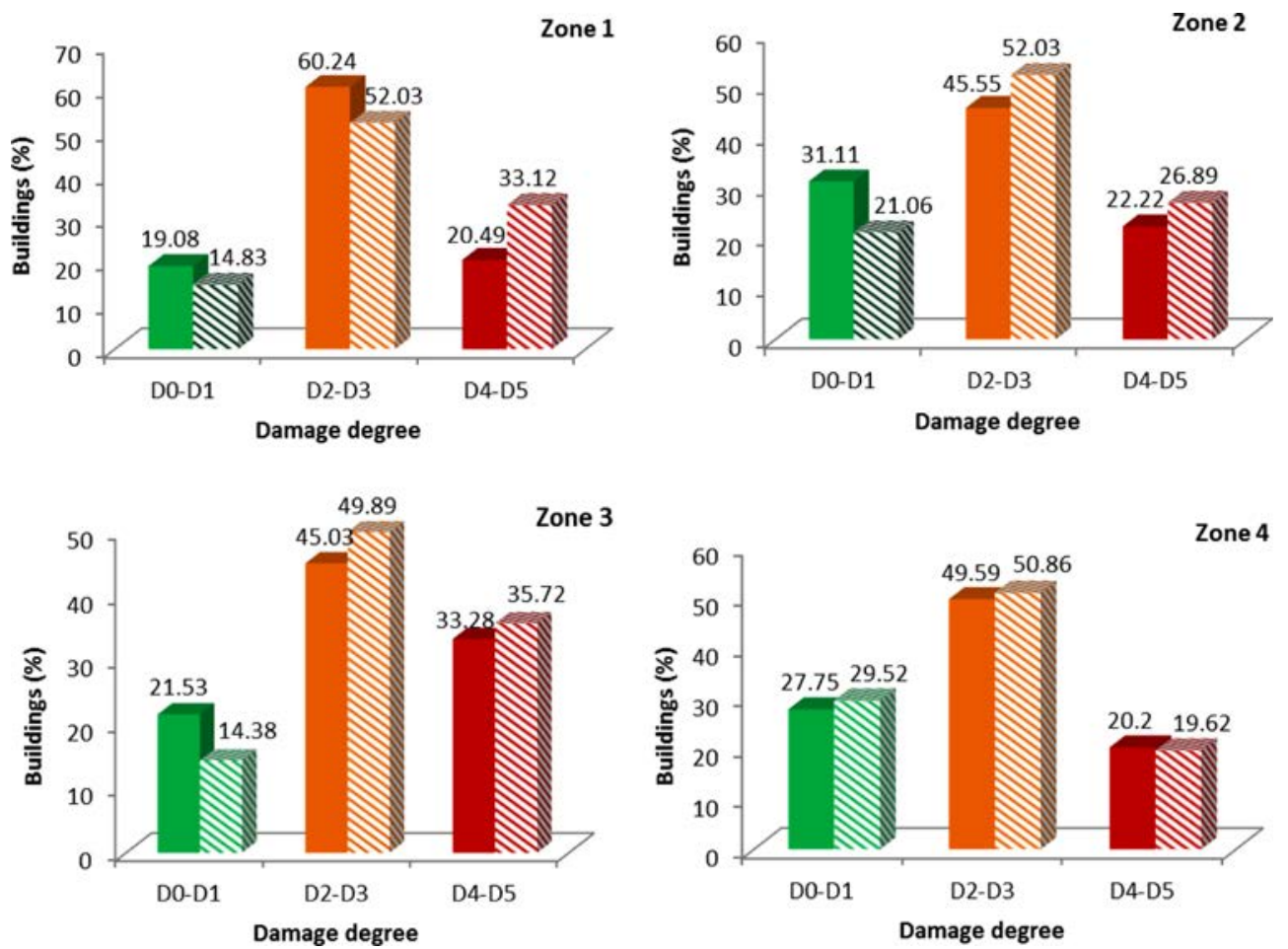

Fig. 11. Comparison of Observed Damage and Simulated Results of the First Scenario for Intensity $\left(I_{0}=I X\right)($ Observed damage: coloured bars, simulation results: hatched bars) 
format. The buildings fragility to earthquake shaking is characterized by vulnerability indices VI. The damage distribution at each location is assessed based on mean damage value $\mu_{D}$ and a value of the $t$ parameter, by the use of the beta probability and the beta cumulative densities, functions given by Eqs. (3) and (4) respectively:

$$
\begin{aligned}
& p_{\beta}(x)=\frac{\Gamma(t)}{\Gamma(r) \Gamma(t-r)} \frac{(x-a)^{r-1}(b-x)^{t-r-1}}{(b-a)^{t-1}} \\
& P_{\beta}(x)=\int_{x}^{a} p_{\beta}(\varepsilon) d \varepsilon
\end{aligned}
$$

where

$a, b, t$, and $r$ are the distribution parameters and $\Gamma$ is the gamma function. According to Giovinazzi (2005), in order to use the beta distribution it is necessary to refer to the damage grades $D k(k=0$ 5) defined by the EMS 98 scale. For this purpose, it is advisable to assign the values 0 and 6 to the parameters $a$ and $b$ respectively.

Parameter $t$, resulting from the probability calculation by the Beta distribution, determines the dispersion of the values, and therefore represents the propagation of uncertainties that can come from the input data. In the aims to test the influence of the $t$ parameter on the results, two values of this parameter are considered in this study: in a first simulation, $t$ is considered equal to 8 , for the three typologies $(T A, T B, T C)$ and in a second simulation, $t$ is considered equal to 8 for the first two typologies (TA and TB) and equal to 4 for the third typology $(T C)$.

Parameter $r$ or equivalently the variance, controls the shape of the distribution and is equal to:

$$
r=t\left(0.007 \mu_{D}^{3}-0.052 \mu_{D}^{2}+0.287 \mu_{D}\right)
$$

The final outcome is the distribution in terms of the six levels defined in EMS98 scale, Grünthal (1998) for each location that is separately considered, is given by Eq. (6):
$P\left(D \geq D_{k}\right)=1-P_{\beta}(k)$

\section{Results and Discussion}

\subsection{First Earthquake Damage Scenario}

The results of the first scenario simulated for a seismic intensity of $I X$ are presented in the EMS 98 damage degrees. In order to compare the error by zones, the maximum $\Delta_{\max }$ and minimum $\Delta_{\min }$ differences between the simulation results and the observed damage are calculated considering the different values of the $t$ parameter and reported in Table 6. To facilitate comparison, damage degrees D4 and D5 are considered as being "red", D2 and D3 as being "orange" and D0 and D1 as being "green". It can be seen that the first simulation, considering a $t$ value equal to 8 for the three typologies gives the better result. Indeed, the biggest difference between the simulated damage and the observed one is $12.69 \%$ (Fig. 11). For the first three zones, compared to the observed damage, this simulation seems to overestimate the D2-D3 and D4-D5 damage degrees and, hence, to underestimate the D0-D1 value. However, for the fourth zone the simulation results are very close to the observed damage.

\subsection{Second Earthquake Damage Scenario}

The distribution of the building stock within the studied area is given in Tables 7 and 8 and illustrated by Fig. 12. From Fig. 12 (a), it can be seen that the two typologies $T P$ and $T 1$ represent the majority of the building park with 43.88 and $31.92 \%$ respectively. The T5 typology ranks third with $12.81 \%$. As regards the distribution of the building park in the five zones, Fig. 12(b) shows that it is the western zone which holds the first rank with $34.78 \%$, followed by the southern zone is with $29.54 \%$ then of the east zone with $22.84 \%$.

Concerning the damage, the zones in which the structural damage

\begin{tabular}{|c|c|c|c|c|c|c|c|c|c|}
\hline \multirow{3}{*}{ Zone } & \multirow{3}{*}{$t$ parameter values } & \multicolumn{6}{|c|}{ Damage } & \multicolumn{2}{|c|}{ Error } \\
\hline & & \multicolumn{3}{|c|}{ Observed } & \multicolumn{3}{|c|}{ Simulated } & \multirow{2}{*}{$\Delta \operatorname{Max}$} & \multirow{2}{*}{$\Delta \operatorname{Min}$} \\
\hline & & Green & Orange & Red & D0-D1 & D2-D3 & D4-D5 & & \\
\hline \multirow{2}{*}{ Zone 1} & $\begin{array}{c}\text { Simulation } 1 \\
\mathrm{t}=8,8,4\end{array}$ & \multirow{2}{*}{19.08} & \multirow{2}{*}{60.24} & \multirow{2}{*}{20.49} & 14.83 & 52.03 & 33.12 & 12.63 & 4.25 \\
\hline & $\begin{array}{c}\text { Simulation } 2 \\
\mathrm{t}=8,8,8\end{array}$ & & & & 12.99 & 56.07 & 30.93 & 10.43 & 4.17 \\
\hline \multirow{2}{*}{ Zone 2} & $\begin{array}{c}\text { Simu lation } 1 \\
t=8,8,4\end{array}$ & \multirow{2}{*}{31.11} & \multirow{2}{*}{45.55} & \multirow{2}{*}{22.22} & 21.06 & 52.03 & 26.89 & 10.05 & 4.67 \\
\hline & $\begin{array}{c}\text { Simulation } 2 \\
\mathrm{t}=8,8,8\end{array}$ & & & & 18.42 & 58.01 & 23.56 & 12.69 & 1.34 \\
\hline \multirow{2}{*}{ Zone 3} & $\begin{array}{c}\text { Simulation } 1 \\
\mathrm{t}=8,8,4\end{array}$ & \multirow{2}{*}{21.53} & \multirow{2}{*}{45.03} & \multirow{2}{*}{33.28} & 14.38 & 49.89 & 35.72 & 7.15 & 2.44 \\
\hline & $\begin{array}{c}\text { Simulation } 2 \\
\mathrm{t}=8,8,8\end{array}$ & & & & 12.79 & 53.48 & 33.72 & 8.74 & 0.44 \\
\hline \multirow{2}{*}{ Zone 4} & $\begin{array}{c}\text { Simulation } 1 \\
\mathrm{t}=8,8,4\end{array}$ & \multirow{2}{*}{27.75} & \multirow{2}{*}{49.59} & \multirow{2}{*}{20.20} & 29.52 & 50.86 & 19.62 & 1.77 & 0.58 \\
\hline & $\begin{array}{c}\text { Simulation } 2 \\
\mathrm{t}=8,8,8\end{array}$ & & & & 24.85 & 61.22 & 13.91 & 11.63 & 2.89 \\
\hline
\end{tabular}
(D3), are the most important are the north zone and the city

Table 6. Comparison between the Simulated Damage for an Intensity $\left(I_{0}=I X\right)$ and the Observed Damage 


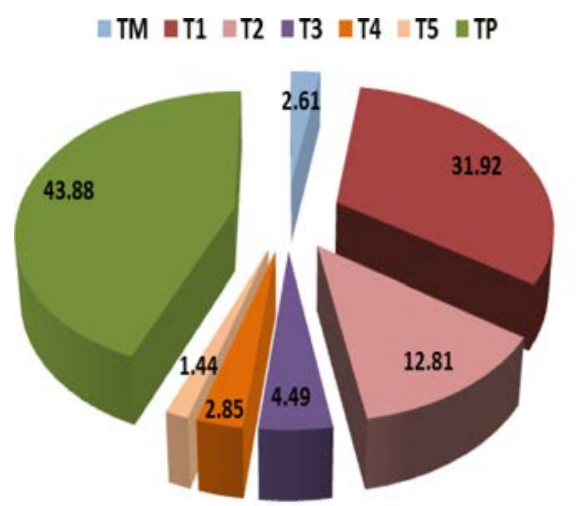

(a)

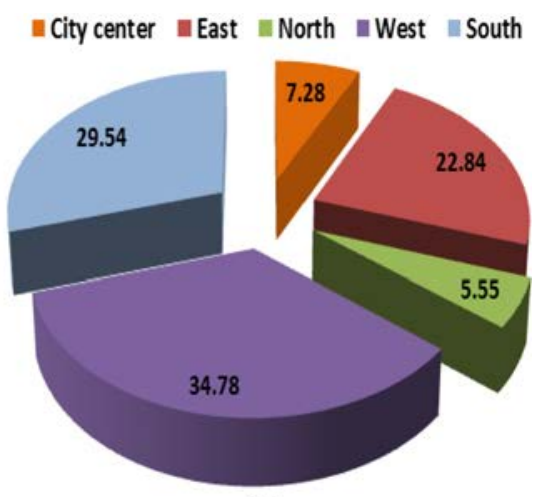

(b)

Fig. 12. Actual Building Stock Distribution in the Studied area in Terms of Percentage of: (a) Typologies, (b) Their Proportion by Zones

Table 7. Building Damage Degree Percentage Versus Buildings' Location for an Intensity $\left(I_{0}=I X\right)$

\begin{tabular}{|c|c|c|c|c|c|c|c|c|c|}
\hline \multirow{2}{*}{ Zones } & \multirow{2}{*}{$\begin{array}{l}\text { Buildings } \\
\text { number }\end{array}$} & \multirow{2}{*}{$\begin{array}{l}\text { Buildings } \\
\text { percentage }\end{array}$} & \multicolumn{6}{|c|}{ Damage degree (\%) } & \multirow{2}{*}{$\begin{array}{c}\text { Structural damage } \\
\quad(>\text { D3) }\end{array}$} \\
\hline & & & D0 & D1 & D2 & D3 & $\mathrm{D} 4$ & D5 & \\
\hline City center & 1,606 & 7.28 & 31.28 & 31.12 & 22.46 & 11.61 & 3.31 & 0.22 & 15.14 \\
\hline East & 5,037 & 22.84 & 48.99 & 29.8 & 14.71 & 5.20 & 1.18 & 0.07 & 6.45 \\
\hline North & 1,224 & 5.55 & 15.94 & 32.73 & 30.24 & 16.47 & 4.38 & 0.25 & 21.1 \\
\hline West & 7,671 & 34.78 & 41.65 & 31.66 & 17.91 & 7.18 & 1.53 & 0.07 & 8.78 \\
\hline South & 6,515 & 29.54 & 46.87 & 32.75 & 15.26 & 4.31 & 0.77 & 0.04 & 5.12 \\
\hline
\end{tabular}

Table 8. Building Damage Degree Percentage Versus Buildings' Typology for an Intensity $\left(I_{0}=I X\right)$

\begin{tabular}{|c|c|c|c|c|c|c|c|c|c|}
\hline \multirow{2}{*}{ Typology } & \multirow{2}{*}{$\begin{array}{l}\text { Buildings } \\
\text { number }\end{array}$} & \multirow{2}{*}{$\begin{array}{l}\text { Buildings } \\
\text { percentage }\end{array}$} & \multicolumn{6}{|c|}{ Damage degrees (\%) } & \multirow{2}{*}{$\begin{array}{l}\text { Structural damage } \\
\quad(>\mathrm{D} 3)\end{array}$} \\
\hline & & & D0 & D1 & D2 & D3 & $\mathrm{D} 4$ & D5 & \\
\hline$T M$ & 575 & 2.61 & 2.95 & 20.24 & 34.96 & 29.30 & 11.52 & 1.02 & 41.84 \\
\hline$T 1$ & 7,039 & 31.92 & 8.27 & 30.08 & 34.74 & 20.79 & 5.79 & 0.33 & 26.91 \\
\hline$T 2$ & 2,826 & 12.81 & 35.17 & 39.96 & 19.48 & 4.82 & 0.56 & 0.01 & 5.39 \\
\hline$T 3$ & 991 & 4.49 & 71.14 & 22.69 & 5.48 & 0.79 & 0.05 & 0.00 & 0.84 \\
\hline$T 4$ & 628 & 2.85 & 39.69 & 38.85 & 16.93 & 4.08 & 0.44 & 0.01 & 4.53 \\
\hline$T 5$ & 317 & 1.44 & 73.76 & 20.44 & 5.15 & 0.60 & 0.04 & 0.00 & 0.64 \\
\hline$T P$ & 9,677 & 43.88 & 62.19 & 28.4 & 7.94 & 1.36 & 0.10 & 0.00 & 1.46 \\
\hline
\end{tabular}

ntructural damage $\quad$ No structural damage

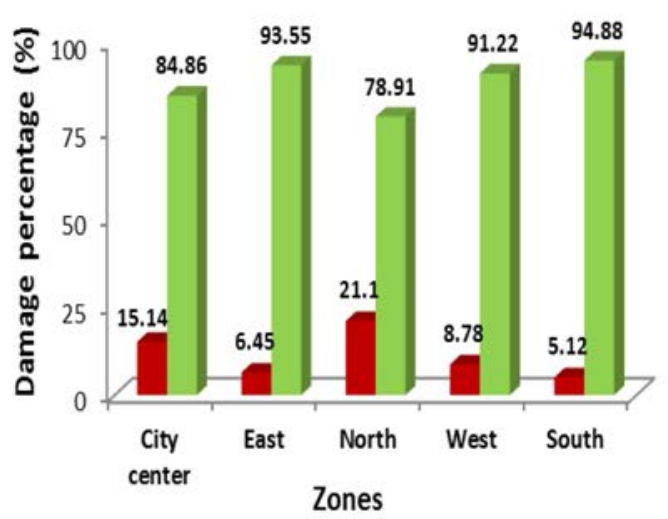

(a)
- Structural damage No structural damage

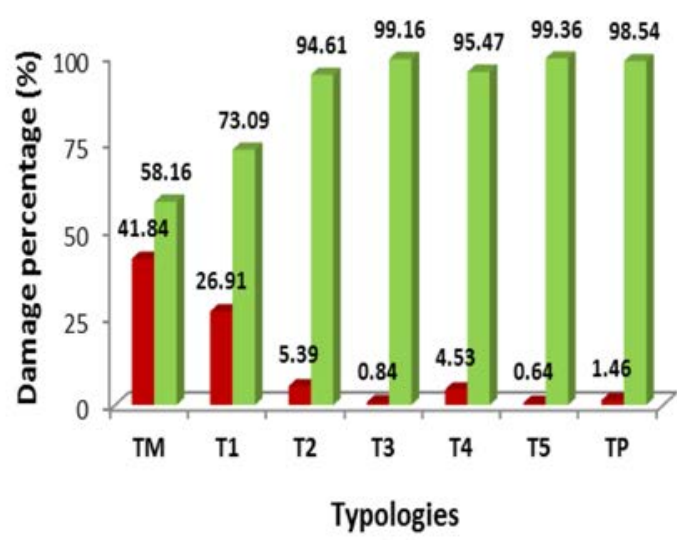

(b)

Fig. 13. Percentage of Structural and no Structural Damage for Intensity $\left(I_{0}=I X \sim X\right)$ in Terms of: (a) Zone, (b) Typology (second damage scenario) 

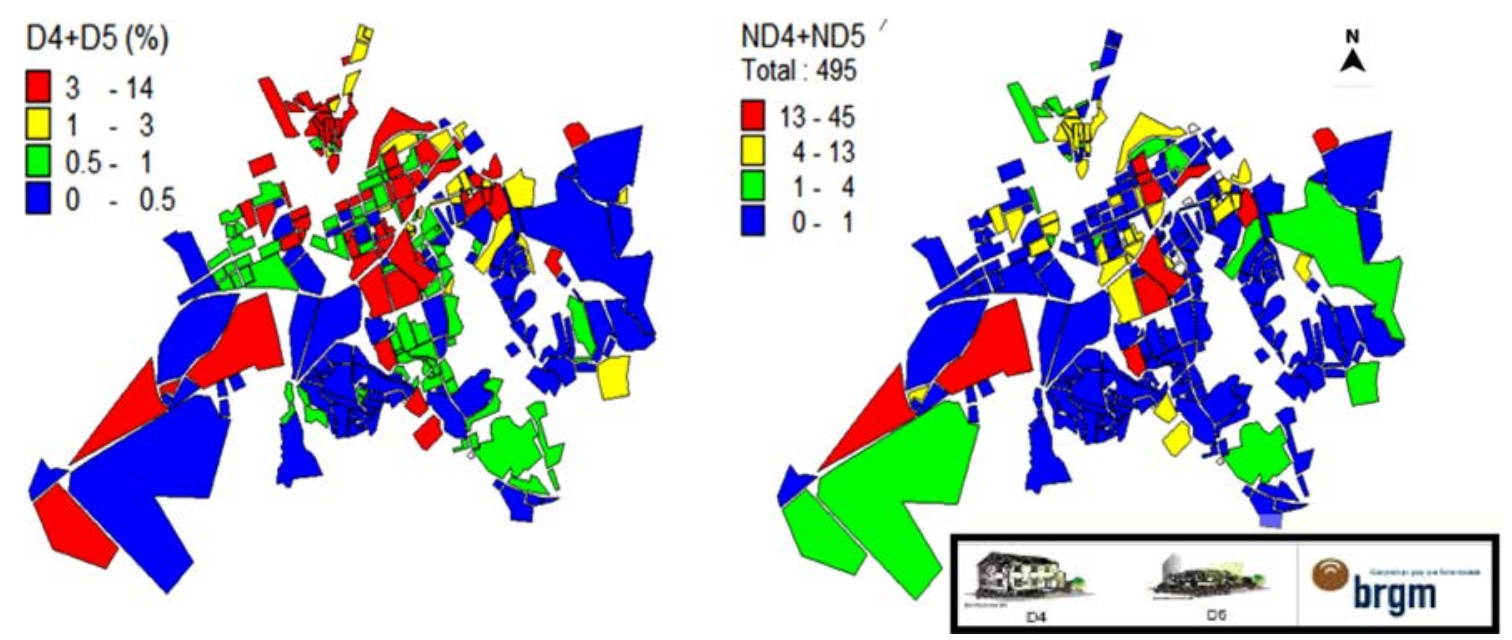

Fig. 14. Second Damage Scenario Results $\left(I_{0}=I X \sim X\right)$ : Buildings' Percentage (left) and Buildings' Number (right) Reaching D4 and D5 Damage Degrees
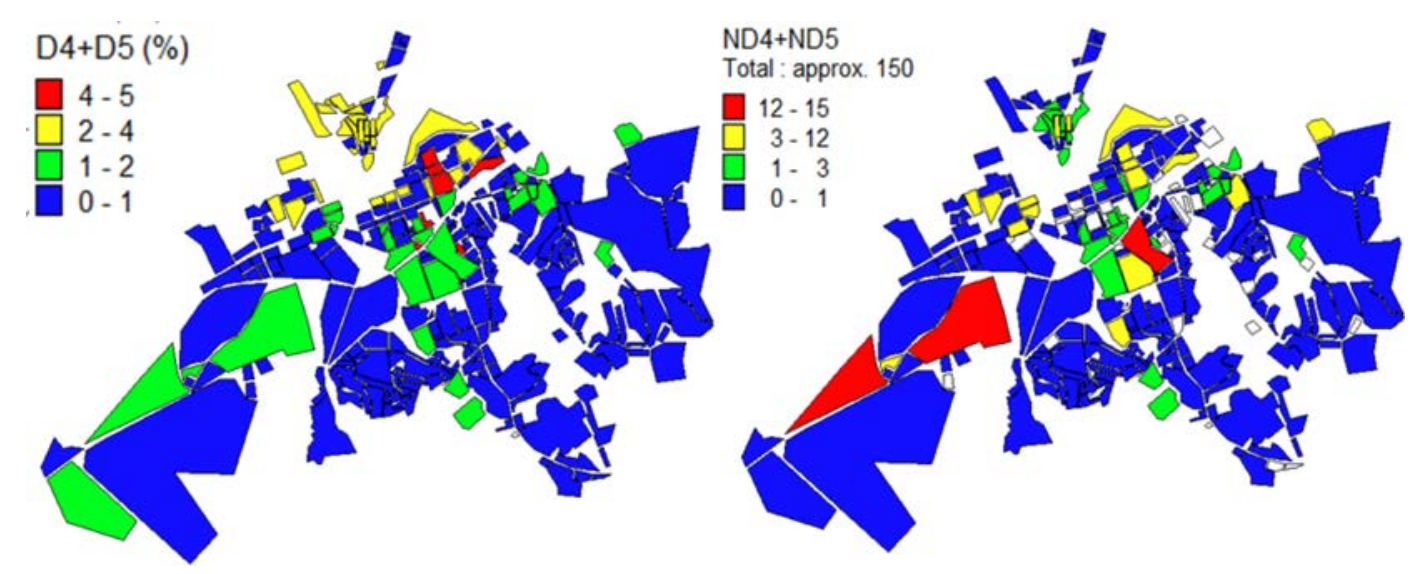

Fig. 15. Third Damage Scenario Results $\left(I_{0}=\right.$ VIII): Buildings' Percentage (left) and Buildings' Number (right) Reaching D4 and D5 Damage Degrees

center (Fig. 13(a)). Hence number of buildings reaching this damage exceeds 500 units, in both zones. Thus, the percentages of buildings that can reach this damage are 21.1 and $15.14 \%$ respectively. This is the result of the concentration of vulnerable typologies $T 1$ and $T M$ in these two zones. In the western and southern zones, the total number of buildings that can reach this damage level is 674 and 334, with a percentages of 8.78 and $5.12 \%$ respectively. These two zones contain a rather large proportion of $T 1$ and $T 2$ typologies, whose vulnerability remains higher than the $T 3, T 4, T 5$ and $T P$ ones. The east zone is the least affected. A total number of 325 buildings representing $6.45 \%$ of those contained in this zone can reach structural damage. This is due to the concentration of TP and newly built $T 3$ and $T 5$ typologies.

Concerning the construction types, the typologies $T M$ and $T 1$ concentrate most of the structural damage (Fig. 13(b)). These typologies, which the total number is 7,584 , are affected by $41.84 \%$ and $26.91 \%$ of this damage, respectively. Therefore, it deserve most attention for the rehabilitation priorities. The $T 2$ typology comes in third position, followed by the $T 4$ typology, as they are affected by $5.39 \%$ and $4.53 \%$ respectively. Due to their seismic design recent, the remaining typologies are less vulnerable and are positioned at the end of the list.

Finally, the result in GIS format of this second scenario is illustrated in Fig. 14, which shows the percentage and number of buildings reaching or exceeding the damage degrees D4 and D5. In this case, earthquake magnitude $\left(M_{S}=7.3\right)$ converted in intensity is slightly higher than $I X$. The percentage of buildings reaching or exceeding these damage is around $14 \%$. Tables 7 and 8 give the results in terms of each degree of damage (D0 to D5) and structural damage for this second scenario, versus of the buildings' location in the city and of their structural typologies, respectively. As concerning the city center, by comparing the simulated results reported in Table 7 and "red" observed damages, represented by zones I and II in Table 1, it seems that the reduction is about $39 \%$. Moreover, this information, which seems to be encouraging, should be considered with special attention. Indeed, the number of buildings has increased from 5,131 in 1980 to 22,053 currently, and so a lower percentage of damaged structures does not necessarily signify that the total 
Table 9. Percentage of Buildings' Damage Degrees for an Intensity $\left(I_{0}=\right.$ VIII) Versus the Location

\begin{tabular}{c|c|c|c|c|c|c|c|c}
\hline \multirow{2}{*}{ Zones } & \multirow{2}{*}{$\begin{array}{c}\text { Nb. of } \\
\text { Buildings }\end{array}$} & \multirow{2}{*}{$\begin{array}{c}\text { Percentage of } \\
\text { buildings (\%) }\end{array}$} & \multicolumn{6}{|c}{ Damage degrees (\%) } \\
\cline { 5 - 10 } & & D0 & D1 & D2 & D3 & D4 & D5 \\
\hline Centre & 1,606 & 7.28 & 46.52 & 30.14 & 16.27 & 5.94 & 1.09 & 0.04 \\
\hline East & 5,037 & 22.84 & 67.58 & 19.86 & 7.07 & 1.89 & 0.26 & 0.01 \\
\hline North & 1,224 & 5.55 & 28.69 & 36.74 & 23.81 & 9.09 & 1.61 & 0.05 \\
\hline West & 7,671 & 34.78 & 55.17 & 28.17 & 12.39 & 3.71 & 0.55 & 0.01 \\
\hline South & 6,515 & 29.54 & 65.58 & 21.80 & 6.75 & 1.52 & 0.18 & 0.00 \\
\hline
\end{tabular}

(a)

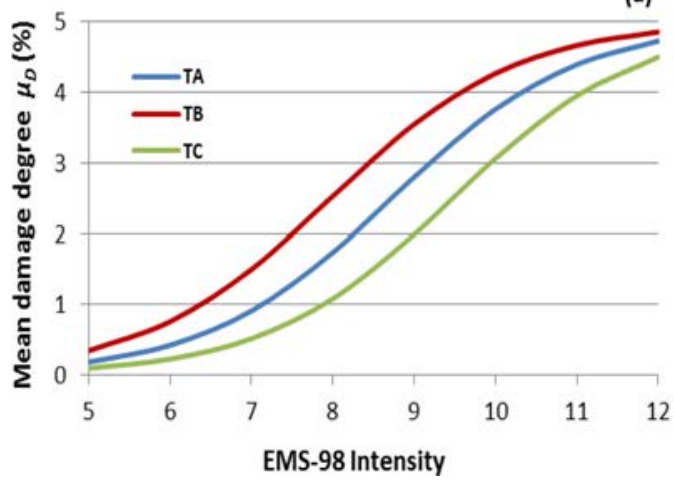

(b)



Fig. 16. Vulnerability Curves of Buildings Typologies: (a) in El Asnam 1980, (b) in Chlef Today

Table 10. Mean Damage Degree for Buildings Typologies Existing in Chlef City in 1980 and Today

\begin{tabular}{|c|c|c|c|c|c|c|c|c|c|}
\hline \multirow{3}{*}{$\begin{array}{l}\text { Urban } \\
\text { situation }\end{array}$} & \multirow{3}{*}{ Typologies } & \multicolumn{8}{|c|}{ Mean Dammage Degree $\mu_{D}(\%)$} \\
\hline & & \multicolumn{8}{|c|}{ EMS Intensity } \\
\hline & & $\mathrm{V}$ & VI & VII & VIII & IX & $\mathrm{X}$ & XI & XII \\
\hline \multirow{3}{*}{1980} & $T A$ & 0.18 & 0.42 & 0.91 & 1.73 & 2.79 & 3.76 & 4.39 & 4.72 \\
\hline & $T B$ & 0.35 & 0.76 & 1.50 & 2.52 & 3.54 & 4.26 & 4.66 & 4.85 \\
\hline & $T C$ & 0.10 & 0.23 & 0.52 & 1.08 & 1.99 & 3.06 & 3.95 & 4.99 \\
\hline \multirow{7}{*}{ Today } & $T M$ & 0.12 & 0.28 & 0.62 & 1.26 & 2.23 & 3.28 & 4.10 & 4.58 \\
\hline & $T 1$ & 0.09 & 0.21 & 0.47 & 1.00 & 1.87 & 2.94 & 3.86 & 4.45 \\
\hline & $T 2$ & 0.03 & 0.09 & 0.21 & 0.47 & 1.00 & 1.87 & 2.94 & 3.86 \\
\hline & $T 3$ & 0.01 & 0.03 & 0.09 & 0.21 & 0.47 & 1.00 & 1.87 & 2.94 \\
\hline & $T 4$ & 0.03 & 0.08 & 0.19 & 0.44 & 0.93 & 1.77 & 2.83 & 3.79 \\
\hline & $T 5$ & 0.01 & 0.03 & 0.08 & 0.19 & 0.44 & 0.93 & 1.77 & 2.83 \\
\hline & $T P$ & 0.02 & 0.05 & 0.12 & 0.28 & 0.63 & 1.28 & 2.25 & 3.31 \\
\hline
\end{tabular}

number of destroyed structures is lower. Since the methodology is based on statistical approaches, it should be noted that the results of the scenarios should not be read as precise values, but as a trend of vulnerability evolution and as a hierarchisation of the vulnerability of urbanised areas.

\subsection{Third Earthquake Damage Scenario}

The converted value of the seismic intensity of a potential earthquake generated by the Red Mountains fault, of maximum magnitude $(\operatorname{Mmax}=6.3)$, is quite close to VIII. The results of the simulation are shown in Table 9 and in Fig. 15. The extent of damage is lower compared to the previous scenario. In this case the structural damage do not exceed $11 \%$ for the north zone which is the most affected (Table 9), while for the previous scenario, it's in the range of $21 \%$ (Table 7) for the same zone.

\subsection{Development of Vulnerability Curves}

Vulnerability curves are developed for existing buildings in Chlef city in 1980 and currently. For the vulnerability indices given in Table 4 , the results of the mean damage $\mu_{D}$ calculation (Eq. (2)) for each typology and for EMS intensity levels ranging from $V$ to $X I I$, are presented in Tables 10 . Fig. 16 clearly reflect the difference between the two urban situations. Considering the intensity range of $I X$ and $X$, which corresponds to that of the $1980 \mathrm{El}$ Asnam earthquake, in the urban situation of 1980 (Fig. 16(a)), the $T B$ and $T A$ typologies were the most vulnerable and exceeded a mean damage grade of 3 for this plage of intensity range. However, it would have required an intensity close to $\mathrm{X}$ to 
cause this same mean damage grade to TC typology. A clear vulnerability reduction is observed for actual buildings typologies (Fig. 16(b)). TM and $T 1$ typologies, which are the most vulnerable, can suffer a D3 mean damage level when an EMS intensity between IX and $\mathrm{X}$ is reached. Note that the typology $T M$ represents the typology $T A$, so $T 1$ encompasses the two typologies $T B$ and $T C$, but after their rehabilitation according to the 1981 version of the Algerian seismic code. Hence, by comparing the curves a reduction in vulnerability is observed for an intensity of $V I I I$, but much less for $I_{0}=X I I$. As an example for the two curves $T A$ and $T M$, it find that $\mu_{\mathrm{D}}$ decreases from $1.73 \%$ to $1.26 \%$ for $I_{0}$ $=V I I I$. While for an intensity of XII, it decreases from $4.72 \%$ to $4.58 \%$. The rest of the typologies do not exceed the level D2 for the intensity corresponding to the earthquake of 1980 and require intensity greater than $X I$ to undergo structural damage, which is an unlikely event in the study area. Due to the improved seismic design of the latter typologies, low vulnerability index values have been assigned (Table 4), therefore this has been reflected in the vulnerability curves.

\section{Conclusions}

The seismic damages scenarios simulated in this work provide us some ideas about the various typologies behaviour in the case of an earthquake. The database platform devloped in this study enable the storage of building features and survey information, seismic vulnerability assessment of existing typologies and damage scenario prediction in Chlef city. For the first scenario, the difference between the observed and simulated damage is around $12 \%$. This result is acceptable for the "urban scale" scenario based on probabilistic approach.

The second scenario, performed considering the actual urban conditions, shows lower percentages of structural damage compared to the 1980 urban conditions. The decrease of the damage is mainly due to the reduction of the seismic vulnerability of existing buildings in Chlef city today, which can be explained by the improved of buildings quality constructed after 1980, due to the application of the seismic code.

Considering these results, it can be conclude that the priority rehabilitation should involve the $T 1$ and $T M$ typologies. However, although these two typologies will tend to disappear completely during the next 10-15 years, the consideration of a general vulnerability index for the $T 1$ typology, is a disadvantage. Hence, it is highly recommended to carry out a more detailed study for the seismic vulnerability of the buildings belonging to this typology taking into account vulnerability indices that are less general than those considered here. Factors that aggravate the vulnerability, such as the maintenance quality, the irregularity of the building, the existence of short columns, the foundation type and the soil morphology should be considered. Relating to most affected zones it is the northern zone and the city center. Emergency planning should be prepared for these two zones.

As concern the third scenario, it can be conclude that a seismic event of 6.3 magnitude, gives lower damages compared to the scenario simulated using $1980 \mathrm{El}$ Asnam earthquake $(M S=7.3)$. In this case, the structural damage do not exceed $11 \%$ for the north zone which is the most affected.

The developed vulnerability curves shows an improvement in the buildings' seismic behaviour in Chlef city today compared to 1980. The rehabilitation of certain buildings belonging to the $T A$ typology, the improvement in the quality of construction, control, construction materials and seismic training of architects and engineers, as well as the collective awareness of the local authorities and citizens of the need of earthquake-resistant construction, are the main causes of this improvement.

The study presented in this article should be extended in order to evaluate the socio-economic consequences, human casualties and homelessness effects of future seismic events, and seismic vulnerability for the various networks in Chlef city. The methodological approach presented in this paper can serve as a decision support tool available to seismic risk managers in Chlef city.

\section{Acknowledgements}

The authors wish to express their sincere thanks to the Construction Technical Control (CTC Chlef), the urban management and the President of the People's Assembly of Chlef city, for the provision of the various data. Gratitude is equally addressed to two anonymous reviewers whose comments contributed to the improvement of the original article.

\section{Notations}

$$
\begin{aligned}
\Gamma & =\text { Gamma function } \\
\mu_{\mathrm{D}} & =\text { Mean damage degree }
\end{aligned}
$$

\section{References}

Ambraseys, N. N., Douglas, J., Sarama, S. K., and Smit, P. M. (2005). "Equations for the estimation of strong ground motions from shallow crustal earthquakes using data from Europe and the Middle East: Horizontal peak ground acceleration and spectral acceleration." Bull. Earthq. Eng., Vol. 3, No. 1, pp. 1-53, DOI: 10.1007/s10518-005-0183-0. Amina, A., Foufa, A., and Benouar, D. (2010). "Investigation of the 1716 Algiers (Algeria) earthquake from historical sources: Effect, damages, and vulnerability." International Journal of Architectural Heritage: Conservation, Analysis, and Restoration, Vol. 4, No. 3, pp. 270-293, DOI: 10.1080/15583050903161352.

Aoudia, A., Vaccari, F., Suhadolc, P., and Meghraoui, M. (2000). "Seismogenic potential and earthquake hazard assessment in the Tell Atlas of Algeria." Journal of Seismology, Vol. 4, pp. 79-98, DOI: 10.1023/A:1009848714019.

Athmani, A. E., Gouasmia, A. E. H., Ferreira, T. M., Vicente, R., and Khemis, A. (2015). "Seismic vulnerability assessment of historical masonry buildings located in Annaba city (Algeria) using non adhoc data survey." Bull. Earthquake Eng., Vol. 13, No. 8, pp. 22832307, DOI: 10.1007/s10518-014-9717-7.

Atkinson, G. and Sonley, E. (2000) "Empirical relationships between modified Mercalli intensity and response spectra." Bull. Seis. Soc. Am., Vol. 90, pp. 537-544, DOI: 10.1785/0119990118. 
Ayadi, A. and Bezzeghoud, M. (2015). "Seismicity of Algeria from 1365 to 2013: Maximum Observed Intensity Map (MOI by 2014)." Seismological Research Letters, Vol. 86, No. 1, pp. 1-9, DOI: 10.1785/0220140075.

Beldjoudi, H., Delouis, B., Heddar, A., Nouar, O. B., and Yelles-chaouche, A. (2012). "The Tadjena Earthquake ( $\mathrm{Mw}=5.0)$ of December 16, 2006 in the Cheliff Region (Northern Algeria): Waveform modelling, regional stresses, and relation with the Boukadir Fault." Pure. Appl. Geophys, Vol. 169, No. 4, pp. 677-691, DOI: 10.1007/s00024-011-0337-8.

Benhamouche, A. (2014). "Seismic risk and damage prediction: case of the buildings in Constantine city (Algeria)." Bull. Earthquake Eng., Vol. 12, No. 6, pp. 2683-2704, DOI: 10.1007/s10518-014-9594-0.

Bertero, V. and Shah, H. (1983). El-Asnam, Algeria earthquake of October 10, 1980. A reconnaissance and engineering report, Report $\mathrm{n}^{\circ}$ CETS CND-022, Earthquake Engineering Research Institute (EERI), California.

Bezzeghoud, M., Dimitrov, D., Ruegg, J. C., and Lammali, K. (1995). "Faulting mechanism of the 1954 and 1980earthquakes from vertical movements modelling." Tectonophysics, Vol. 249, No. 3, pp. 249266, DOI: 10.1016/0040-1951(95) 00032-I.

Boukri, M., Farsi, M., Mebarki, A., Belazougui, M., Amellal, O., Mezazigh, B., Bourenane, H., Benhamouche, A., and Guessoum, N. (2014). "Seismic risk and damage prediction: Case of the buildings in Constantine city (Algeria)." Bull. Earthquake Eng., Vol. 12, No. 6, pp. 2683-2704, DOI: 10.1007/s10518-014-9594-01001.

Dolce, M., Masi, A., Marino, M., and Vona, M. (2003). "Earthquake damage scenarios of Potenza town (Southern Italy) including site effects." Bull. Earthquake Eng., Vol. 1, No. 1, pp. 115-140, DOI: 10.1023/A:1024809511362.

Farsi, M. and Lazzali, F. (2003). HOUSING REPORT Single-family reinforced concrete frame houses, Report No. 103, Earthquake Engineering Research Institute (EERI) and International Association for Earthquake Engineering (IAEE), Oakland.

Ferreira, T. M., Maio, R., and Vicente, R. (2017). "Analysis of the impact of large scale seismic retrofitting strategies through the application of a vulnerability-based approach on traditional masonry buildings." Earthquake Engineering and Engineering Vibration, Vol. 16, No. 2, pp. 329-348, DOI: 10.1007/s11803-017-0385-x.

Giovinazzi, S. (2005). Vulnerability assessment and the damage scenario in seismic risk analysis, $\mathrm{PhD}$ Thesis, University of Florence, Italy.

Grünthal, G. (1998). European macroseismic scale 1998, Centre Européen de Géodynamique et de Séismologie, Luxemburg.

Guettiche, A., Guéguen, P., and Mimoune, M. (2017). "Seismic vulnerability assessment using association rule learning: Application to the city of Constantine, Algeria." Natural Hazards, Vol. 86, No. 3, pp. 12231245, DOI: 10.1007/s11069-016-2739-5.

Hamdache, M., Peláez José, A., Talbi, A., and López Casado, C. (2010). "A unified catalog of main earthquakes for northern Algeria from A.D. 856 to 2008." Seismological Research Letters, Vol. 81, No.5, pp. 732-739, DOI: 10.1785/gssrl.81.5.732.

Lagomarsino, S. and Giovinazzi, S. (2006). "Macroseismic and mechanical models for the vulnerability and damage assessment of current buildings." Bull. Earthquake Eng., Vol. 4, No. 4, pp. 415-443, DOI: 10.1007/s10518-006-9024-z.

Lamego, P., Laurenço, P. B., Sousa, M. L., and Marques, R. (2016). "Seismic vulnerability and risk analysis of the old building stock at urban scale: Application to a neighbourhood in Lisbon." Bull. Earthquake Eng., Vol. 15, No. 7, pp. 2901-2937, DOI: 10.1007/ s10518-016-0072-8.

Lantada, N., Irizarry. J., Barbat. A.H., Goula, X., Roca, A., Susagna, T., and Pujades, L. G. (2010). "Seismic hazard and risk scenarios for Barcelona, Spain, using the Risk-UE vulnerability index method." Bull. Earthquake Eng., Vol. 8, No. 2, pp. 201-229, DOI: 10.1007/ s10518-009-9148-z.

Layadi, K., Semmane, F., and Yelles-Chaouche, A. K. (2016). "Siteeffects investigation in the City of Chlef (formerly El-Asnam), Algeria, using earthquake and ambient vibration data." Bull. Seis. Soc. Am., Vol. 106, No. 5, pp. 1-12, DOI: 10.1785/0120150365.

Meghraoui, M. and Pondrelli, S. (2012). "Active tectonics around the Mediterranean. Active faulting and transpression tectonics along the plate boundary in North Africa." Annals of Geophysics, Vol. 55, No. 5, pp. 955-967, DOI: 10.4401/ag-4970.

Meghraoui, M., Jaegy, R., Lammali, K., and Albarède, F. (1988). "Late Holocene earthquake sequences on the El Asnam (Algeria) thrust fault. " Earth and Planetary Science Letters, Vol. 90, No. 2, pp. 187203, DOI: 10.1016/0012-821X(88)90100-8.

Milutinovic, Z. V. and Trendafiloski, G. S. (2003). "An advanced approach to earthquake risk scenarios with applications to different European towns, WP4: Vulnerability of current buildings." European Commission, p. 110.

Murphy, J. R. and O'Brien, L. J. (1977). "The correlation of peak ground acceleration amplitude with seismic intensity and other physical parameters." Bull. Seis. Soc. Am., Vol. 67, No. 3, pp. 877-915.

NISEE, Earthquake Engineering Online Archive NISEE e-Library. http:// nisee.berkeley.edu/elibrary/about.html, Accessed 08 February 2015.

Novelli, V. I., D’Ayala, D., Makhloufi, N., Benouar, D., and Zekagh, A. (2015). "A procedure for the identification of the seismic vulnerability at territorial scale. Application to the Casbah of Algiers." Bull. Earthquake Eng., Vol. 13, pp. 177-202, DOI: 10.1007/s10518-014-9666-1.

Petrovski, J., Petrovski, D., Auramov, A., Sesov, N., Salhi, N., Farsi, M., Milutinovic, A., and Dojcinovski, D. (1981). Studies for elaboration of the code for repair and strengthening of damaged buildings in the region of El Asnam-Vol. VII, Analysis of simple structures and damage distribution analysis, Report IZIIS82-55-7, Institute of Earthquake Engineering and Engineering Seismology, University of Kril and Metodij, Skopie.

RPA (2003). Règles Parasismiques Algériennes, Report DTR BC 2-48, Centre National de Recherche Appliquée en Génie Parasismique, Alger.

Sedan, O., Negulescu, C., Terrier, M., Roulle, A., Winter, T., and Bertil, D. (2013) "Armagedom- A tool for seismic risk assessment illustrated with applications." J. Earthquake Eng., Vol. 17, No. 2, pp. 253-281, DOI: 10.1080/13632469.2012.726604.

Senouci, A., Bard, P. Y., Farsi, M. N., Beck, E., and Cartier, S. (2013). "Robustness and uncertainties of seismic damage estimates at urban scale: A methodological comparison on the example of the city of Oran (Algeria)." Bull. Earthquake Eng., Vol. 11, No. 4, pp. 11911215, DOI: 10.1007/s10518-012-9406-3.

Veludo, I., Teves-Costa, P., and Bard, P. (2013). "Damage seismic scenarios for Angra do Heroísmo, Azores (Portugal).” Bull. Earthquake Eng., Vol. 11, pp. 423-453, DOI: 10.1007/s10518-012-9399-y.

Wald, D., Quitoriano, V., Heaton, T., Kanamori, H., Scrivner, C., and Worden, C. (1999). "TriNetShakeMaps: Rapid generation of peak ground motion and intensity maps for earthquakes in southern California." Earthquake Spectra, Vol. 15, pp. 537-555, DOI: 10.1193/1.1586057.

Woodward-Clyde Consultants (1984). Microzonation sismique de la région d'Ech Chliff Algérie, Technical Report, Ministere de l'habitat et de l'urbanisme, Alger.

Yelles-Chaouche, A., Boudiaf, A., Djellit, H., and Bracene, R. (2006). "La tectonique active de la région nord-Algérienne." $C R$ Geoscience, Vol. 338, pp. 126-139, DOI: 10.1016/j.crte.2005.11.002. 